\title{
STUDI PEMAKAIAN PESTISIDA PADA PETANI KENTANG DI DESA DIENG KECAMATAN KEJAJAR KABUPATEN WONOSOBO TAHUN 2015
}

\author{
Fatmawati $^{1)}$, Suparmin'2) \\ Jurusan Kesehatan Lingkungan, Politeknik Kesehatan Kemenkes Semarang, \\ Jl.Raya Baturaden KM 12 Purwokerto, Indonesia.
}

\begin{abstract}
Abstrak
Desa Dieng, Kecamatan Kejajar, Kabupaten Wonosobo sebagian besar wilayahnya digunakan sebagai lahan pertanian, berdasarkan survey pendahuluan yang peneliti lakukan, dari 2.203 jumlah penduduk Desa Dieng, 1.371 (67,45\%) diantaranya adalah petani kentang. Tingginya jumlah petani kentang di Desa Dieng menunjukkan adanya pemakaian pestisida sehingga dimungkinkan ada residu pestisida baik di lingkungan maupun di produk panen yang dihasilkan. Tujuan penelitian adalah mendeskripsikan pemakaian pestisida pada petani kentang. Penelitian ini menggunakan jenis penelitian deskriptif analitik, dengan wawancara, observasi dan pemeriksaan residu pestisida pada tanah dan kentang di Laboratorium Pengujian dan Penelitian UGM menggunakan metode Gaskromatografi (GC).Hasil penelitian adalah Organophospat merupakan golongan yang paling banyak digunakan dengan presentase 72,46\%. Jumlah pestisida yang digunakan petani kentang dalam bentuk powder mencapai $13.000 \mathrm{~g}$ sekali aplikasi, liquid mencapai $7.500 \mathrm{ml}$ dan granule mencapai $3.000 \mathrm{~g}$. Seluruh petani kentang (100\%) mengaplikasikan pestisida dengan cara disemprot. Hasil dari penilaian K3 menunjukkan bahwa 73,18 \% baik dan 26,82 \% buruk. Hasil pengujian residu pestisida golongan Organochlorin pada tanah mendapatkan hasil 61,47 \% untuk parameter uji p:p-DDT. Kesimpulan menunjukkan pemakaian pestisida petani kentang di Desa Dieng menggunakan pestisida dengan fungsi fungisida, insektisida dan akarisida dalam bentuk powder, liquid, maupun granule.
\end{abstract}

Kata Kunci : Pestisida, Tanah, Kentang, dan Kesehatan Lingkungan

\begin{abstract}
Dieng sub-district, Kejajar District, Wonosobo Regency where most of the area is used as agricultural, based on preliminary survey, from 2,203 Dieng's total population, 1,371 (67.45\%) of them were potato farmers. The high numbers of potato farmers in Dieng indicate possible use of pesticide so that there is a good pesticide residue, both in the environment and in harvest products. The research objective was to describe the potato farmer's pesticides usage. The research design used was descriptive analytic study, with interviews, observations and measuring pesticide residues in soil and potatoes in the Testing and Research Laboratory of UGM using Gaskromatografi $(G C)$. The research results shows that Organophosphate was the most widely used with percentage for $72.46 \%$. The amount of pesticides used by potatoes farmers up to 13,000 $\mathrm{g}$ in powder form, in the liquid form reached 7,500 $\mathrm{ml}$ and in the granule form reached 3,000 g. All potatoes farmers (100\%) applied pesticides through spraying. The Occupational Health and Safety assessment results showed that $73.18 \%$ in the good category and $26.82 \%$ in the bad category. The pesticide residue measurement shows that Organochlorin contained on the soil was $61.47 \%$ for the p:p-DDT test parameter. The conclusion was; the potato farmers pesticide used as fungicides, insecticides and akaricide in the powder, liquid, or granule form.
\end{abstract}

Keywords : Pesticide, Soil, Potato, and Environment Health

\section{PENDAhuluan}

Menurut Peraturan Pemerintah Tahun 2014 tentang Kesehatan Lingkungan, Pasal 39 ayat 2 menyebutkan bahwa salah satu unsure yang mengakibatkan gangguan lingkungan adalah pestisida.

Jumlah merek pestisida yang beredar di Indonesia semakin banyak dari tahun ke tahun. Saat ini berdasarkan data Komisi Pestisida di bawah Kementerian Pertanian sudah terdaftar fungisida sebanyak 350 merek, herbisida sebanyak 600 merek dan insektisida sebanyak 800 merek, dengan izin tetap. Jumlah ini belum termasuk produk yang illegal. (Kementrian Pertanian, 22 April 2012, http://vivanews.com). 
Kebiasaan petani dalam menggunakan pestisida kadang - kadang menyalahi aturan , selain dosis yang digunakan melebihi takaran petani juga sering mencampur beberapa jenis pestisida. Hal ini akan memperbanyak residu pestisida di lingkungan dan menimbulkan dampak lebih besar bagi lingkungan maupun kesehatan manusia. Penggunaan dan penyemprotan yang menyalahi aturan juga berdampak buruk bagi lingkungan dan manusia, karena pestisida merupakan senyawa kimiawi yang dibuat sebagai racun. Sifat dan potensi racun dari pestisida tidak hanya berlaku bagi hama yang menjadi target, namun mampu memberikan dampak negative terhadap lingkungan (tanah, air, tanaman yang dihasilkan) dan kesehatan manusia. ( keracunan, kecacatan, bahkan kematian).

Dataran Tinggi Dieng merupakan wilayah pegunungan dimana sebagian besar wilayahnya digunakan sebagai lahan pertanian. Salah satunya adalah Desa Dieng ,Kecamatan Kejajar, Kabupaten Wonosobo yang sebagian besar wilayahnya dijadikan lahan pertanian kentang. Berdasarkan survey pendahuluan yang peneliti lakukan di Desa Dieng, dari 2.203 jumlah penduduk Desa Dieng, 1.371 diantaranya adalah petani kentang. Pada zaman dahulu Dieng merupakan tanah emas, dimana jika menanam kentang 1 kwintal akan menghasilkan kentang sebanyak 2-3 ton saat panen, tetapi dengan terus - menerusnya penggunaan pestisida maka kualitas tanah menjadi semakin buruk, yang ditandai dengan tanaman apapun sulit atau bahkan tidak bisa tumbuh jika tidak di semprot pestisida. Penyemprotan pestisida dilakukan 3 hari sekali ketika daun kentang mulai tumbuh (daun muda), tetapi jika daun kentang mulai dewasa, frekuensi penyemprotan ditingkatkan menjadi 5 hari sekali hingga saat panen tiba dengan dosis 5 sendok pestisida untuk 1 drum air. Petani di Desa Dieng juga sebagian besar tidak menggunakan Alat Pelindung Diri dengan alasan tidak nyaman di gunakan saat penyemprotan. (Wawancara, Muhammad Yusuf, 23 Oktober 2014).

Survey pendahuluan tersebut menunjukkan bahwa ada pemakaian pestisida di Desa Dieng, sehingga dimungkinkan ada residu pestisida baik di lingkungan maupun di produk panen yang dihasilkan. Tujuan dari penelitian ini untuk mengetahui pemakaian pestisida pada petani kentang di Desa Dieng, Kecamatan Kejajar, Kabupaten Wonosobo Tahun 2015.

\section{BAHAN DAN METODE}

Jenis penelitian yang digunakan adalah deskriptif analitis artinya menggambarkan pemakaian pestisida pada petani kentang dan pemeriksaan residu pestisida pada tanah dan kentang di lahan pertanian kentang Desa Dieng , Kecamatan Kejajar, Kabupaten Wonosobo.

Subyek penelitian pada penelitian ini adalah petani kentang Di Desa Dieng dan tanah serta kentang yang diambil di lahan pertanian kentang
Desa Dieng, Kecamatan Kejajar, Kabupaten Wonosobo, Tahun 2015.

Cara mendapatkan subyek petani kentang yang diukur menggunakan metode pengambilan sampel menurut Suharsimi Arikunto (2010, hal. 134), yaitu apabila subyek pengukuran <100 maka subyek diukur semua, tetapi apabila subyek pengukuran $>100$ maka subyek yang diukur $10 \%-15 \%$ atau $20 \%-25 \%$ atau lebih. Pada penelitian ini jumlah petani kentang yang dijadikan pegukuran 1.371 orang, karena >100 maka diambil sampel sebanyak 10\%. Sehingga petani kentang yang di jadikan subyek penelitian sebanyak 138 orang. Teknik pengambilan sampel menggunakan incidental sampling menurut Prof Dr. Sugiyono (2011, hal. 67), adalah tekhnik penentuan sampel berdasarkan kebetulan, yaitu siapa saja yang secara kebetulan/incidental bertemu dengan peneliti dapat digunakan sebagai sampel, bila dipandang orang yang kebetulan bertemu itu cocok sebagai sumber data.

Teknik pengambilan sample tanah dan kentang menggunakan composite sampling yaitu tekhnik pengambilan contoh dalam beberapa titik pengambilan,kemudian contoh - contoh tersebut disatukan dan dicampur aduk sampai merata, kemudian dianalisis. (Brush et al dalam Suganda dkk, 2002, hal. 21). Cara analisis data yang dipakai yaitu analisis dengan menggunakan tabel, grafik dan narasi.

\section{III.HASIL DAN PEMBAHASAN}

Hasil

Data yang diperoleh dari penelitian dapat diketahui bahwa petani kentang di Desa Dieng, Kecamatan Kejajar, Kabupaten Wonosobo mayoritas menggunakan pestisida dengan fungsi sebagai Fungisida yaitu 12 merk (48\%) dari 25 merk (100\%) pestisida yang diperoleh. Sedangkan golongan pestisida yang telah teridentifikasi menggunakan berjumlah 12 golongan, dan Organophospat merupakan golongan yang paling banyak digunakan yaitu 100 pengguna $(72,46 \%)$ dari 138 pengguna (100\%).

Jumlah pestisida yang digunakan petani kentang di Desa Dieng, Kecamatan Kejajar, Kabupaten Wonosobo terdiri dari 3 Bentuk yaitu Powder, Liquid dan Granule.

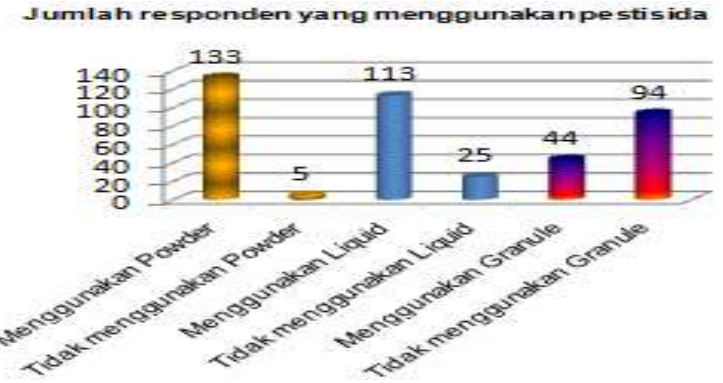

Gambar 1.1. Jumlah Responden yang menggunakan pestisida dalam bentuk Powder, Liquid dan Granule 
Secara rinci jumlah pestisida yang digunakan petani kentang di Desa Dieng, Kecamatan Kejajar, Kabupaten Wonosobo dalam bentuk Powder, Liquid dan Granule adalah sebagai berikut :

Tabel 1.1 Jumlah pestisida dalam bentuk Powder yang digunakan petani kentang di Desa Dieng, Kecamatan Kejajar, Kabupaten Wonosobo Tahun 2015.

\begin{tabular}{llll}
\hline No & $\begin{array}{l}\text { Jumlah } \\
\text { Pestisida }(g)\end{array}$ & $\begin{array}{l}\text { Jumlah } \\
\text { Responden }\end{array}$ & \% \\
\hline 1 & $1-3.250$ & 99 & 74,43 \\
2 & $3.251-6500$ & 29 & 21,80 \\
3 & $6.501-9.750$. & 1 & 0,75 \\
4 & $9.751-13.000$ & 4 & 3,02 \\
Jumlah & 133 & 100 \\
\hline
\end{tabular}

Sumber : Petani kentang Desa Dieng Kecamtan Kejajar, Kabupaten Wonosobo Tahun 2015

Tabel 1.1 Jumlah pestisida dalam bentuk Liquid yang digunakan petani kentang di Desa Dieng, Kecamatan Kejajar, Kabupaten Wonosobo Tahun 2015.

\begin{tabular}{llll}
\hline \multirow{2}{*}{ No } & $\begin{array}{l}\text { Jumlah } \\
\text { Pestisida (ml) }\end{array}$ & $\begin{array}{l}\text { Jumlah } \\
\text { Responden }\end{array}$ & $\%$ \\
\hline 1 & $1-1.875$ & 102 & 90,26 \\
2 & $1.876-3.750$ & 9 & 7,96 \\
3 & $3.751-5.625$ & 1 & 0,89 \\
4 & $5.626-7.500$ & 1 & 0,89 \\
Jumlah & 113 & 100 \\
\hline
\end{tabular}

Sumber : Petani kentang Desa Dieng Kecamtan Kejajar, Kabupaten Wonosobo Tahun 2015

Tabel 1.1 Jumlah pestisida dalam bentuk Granule yang digunakan petani kentang di Desa Dieng, Kecamatan Kejajar, Kabupaten Wonosobo Tahun 2015.

\begin{tabular}{llll}
\hline No & $\begin{array}{l}\text { Jumlah } \\
\text { Pestisida (g) }\end{array}$ & $\begin{array}{l}\text { Jumlah } \\
\text { Responden }\end{array}$ & $\%$ \\
\hline 1 & $1-750$ & 34 & 77,27 \\
2 & $751-1.500$ & 7 & 15,91 \\
3 & $1.501-2.250$ & 1 & 2,27 \\
4 & $2.251-3.000$ & 2 & 4,55 \\
Jumlah & 44 & 100 \\
\hline
\end{tabular}

Sumber : Petani kentang Desa Dieng Kecamtan

Kejajar, Kabupaten Wonosobo Tahun 2015

Seluruh petani kentang Desa Dieng yang dijadikan subyek penelitian mengaplikasikan pestisida dengan cara disemprot, frekwensi penyemprotan bervariasi untuk sekali periode tanam yaitu 15 - 20 kali, 20 - 25 kali dan 20 - 30 kali. Keselamatan dan Kesehatan petani kentang Desa dieng 26,82 \% dalam kategori buruk, sedangkan $73,18 \%$ dalam kategori baik. Pengkategorian Keselamatan dan Kesehatan Kerja diperoleh menggunakan pengkategorian menurut Masri Singarimbun (1997), dengan cara penilaian :

$$
\text { Nilai }=\frac{\text { Jumlah jawaban Ya }}{\text { Jumlah seluruh pertanyaan }} 100 \%
$$

Kriteria Penilaian :

$>50 \%$ adalah baik

$<50 \%$ adalah buruk
Hasil pengujian Laboratorium untuk golongan Organochlorin pada kentang Benzenhexachlor $<1,55$ $\mu \mathrm{g} / \mathrm{kg}$, Heptachlor $<2,00 \mu \mathrm{g} / \mathrm{kg}$, Heptachlorpropoxide $<1,45 \mu \mathrm{g} / \mathrm{kg}$, Aldrin $<2,50 \mu \mathrm{g} / \mathrm{kg}$, Dieldrin <7, 80 $\mu \mathrm{g} / \mathrm{kg}$, Endosulfan $<7,40 \mu \mathrm{g} / \mathrm{kg}$, Endrin $<8,30 \mu \mathrm{g} / \mathrm{kg}$, Methoxychlor <5,30 $\mu \mathrm{g} / \mathrm{kg}$ dan p:p-DDT 61,47 $\mu \mathrm{g} / \mathrm{kg}$. Hasil tersebut menunjukkan bahwa tanah positif mengandung p;p-DDT sebesar $61,47 \mu \mathrm{g} / \mathrm{kg}$. Sedangkan 8 parameter uji lainya menunjukkan hasil di bawah batas kemampuan deteksi alat, dimana data tersebut dapat menunjukkan hasil di bawah angka batas kemampuan deteksi alat, dan dapat juga menunjukkan hasil negative (0).

Sedangkan untuk pemeriksaan Organophospat pada Kentang mendapatkan hasil Diazinon $<3,70$ $\mu \mathrm{g} / \mathrm{kg}$, Parathion $<6,40 \mu \mathrm{g} / \mathrm{kg}$, Ethion $<4,30 \mu \mathrm{g} / \mathrm{kg}$, Profenofos $<4,80 \mu \mathrm{g} / \mathrm{kg}$, Malathion $<0,50 \mu \mathrm{g} / \mathrm{kg}$ dan Chlorphyrifos $<0,33 \mu \mathrm{g} / \mathrm{kg}$, dari 6 parameter uji menunjukkan semuanya di bawah batas kemampuan deteksi alat, dimana data tersebut dapat menunjukkan hasil di bawah angka batas kemampuan deteksi alat. dan dapat juga menunjukkan hasil negative (0).

\section{Pembahasan}

Masing - masing pestisida mempunyai efek fisiologis yang berbeda - beda tergantung dari kandungan zat aktif dan sifat fisik dari pestisida tersebut. Banyaknya jenis pestisida yang digunakan menyebabkan beragam paparan pada tubuh pada petani yang mengakibatkan reaksi sinergik dalam tubuh.

Fungisida merupakan bahan yang digunakan secara ekstensif sebelum dan sesudah panen, untuk mencegah terjadinya kerusakan pada tumbuhan akibat spora fungi, pada kondisi di bawah optimum terutama kelembaban dan temperature. Fungisida biasanya menyebabkan efek akut terhadap manusia dengan $\mathrm{LD}_{50}: 800-10.000 \mathrm{mg} / \mathrm{kg}$ berat badan. Bila terpapar pestisida melalui kulit maka akan terjadi iritasi dan dermatitis. Kebanyakan fungisida dapat menyebabkan iritasi pada saluran pernafasan, selaput lender, membrane mata, dan hidung. Semua fungisida bersifat sitotoksik, dank arena mutagenetik, maka dapat menyebabkan mutasi gen, kangker dan teratogenik. Beberapa contoh fungisida yang umum digunakan adalah Ditiocarbamat, terutama etilen bisditio karbamat kelompok yang didegradasi menjadi etilen tio urea yang diketahui sebagai anti tiroid, zat yang mutagenic, karsinogenik, dan tetatogenik pada hewan uji. Merkuri organic beracun bagi hati, ginjal, dan terutama pada system saraf (pusat dan parifer). Salah satu diantaranya menyebabkan penyakit Minamata. (Juli Soemirat, 2009, hal.157).

Golongan Organophospat sering disebut organic phospat, phosphorus insecticides, phosathes, phosphates insecticides dan phosphorus esters atau phosphoric acid eters. Mereka itu adalah derivate dari phosphoric acid dan biasanya sangat toksik untuk hewan bertulang belakang. Golongan organophospat 
struktur kimianya dan cara kerjanya berhubungan erat dengan gas syaraf. Organophospat selain toksik terhadap hewan bertulang belakang ternyata tidak stabil dan nonpersisten, sehingga golongan ini dapat menggantikan organochlorin, khususnya untuk menggantikan DDT. (Subiyakto Sudarmo, 1995, hal.35)

Jumlah pestisida yang digunakan petani kentang berbeda - beda tiap petani, tergantung dari luas lahan, karakteristik tanaman, dan kebutuhanya. Pestisida yang digunakan petani kentang di Desa Dieng, Kecamatan Kejajar, Kabupaten Wonosobo berbentuk Powder (tepung), Liquid (cair) dan Granule (butiran). Untuk membedakan bentuk pestisida dapat dilihat dari merk pestisida, biasanya terdapat singkatan untuk menunjukkan bentuk pestisida di belakang merk dagang. Berdasarkan hasil survey yang telah dilakukan kepada 138 petani kentang, jumlah pestisida dalam bentuk Powder ( tepung) terendah pemakainya adalah $250 \mathrm{~g}$, dan terbanyak mencapai 13.000 g. Pestisida dalam bentuk Liquid (cair) terendah pemakaianya adalah $125 \mathrm{ml}$ dan terbanyak mencapai $7.500 \mathrm{ml}$, sedangkan dalam bentuk Granule (butiran) pemakaian terendah berjumlah $150 \mathrm{~g}$ dan terbanyak mencapai $3.000 \mathrm{~g}$.

Komposisi pestisida formulasi tepung pada umumnya terdiri atas bahan aktif dan bahan pembawa seperti tanah liat atau talek (biasanya 50 75 persen). Untuk mengenali pestisida formulasi tepung biasanya di belakang nama dagang tercantum singkatan WP (wettable powder) atau WSP (water soluble powder). Pestisida yang berformulasi cairan emulsi meliputi pestisida yang di belakang nama dagang diikuti dengan singkatan ES (emulsifible solution), WSC (water soluble concentrate), E (emulsifiable) dan S (solution). Pestisida bentuk ini disebut bentuk cairan emulsi karena berupa cairan pekat yang dapat di campur dengan air dan akan membentuk emulsi. Formulasi butiran biasanya hanya digunakan pada bidang pertanian sebagai insektisida sistematik. Dapat digunakan bersamaan waktu tanam untuk melindungi tanaman pada umur awal. Pestisida formulasi butiran biasanya di belakang nama dagang tercantum singkatan $\mathrm{G}$ atau WDG (water dispersible granule).( Subiyakto Sudarmo, 1995, hal. 22 )

Cara aplikasi pestisida yang dilakukan petani kentang di Desa Dieng, Kecamatan Kejajar, Kabupaten Wonosobo berdasarkan hasil survey dengan menggunakan kuesioner adalah dari 138 petani kentang yang dijadikan subyek penelitian seluruhnya (100\%) mengaplikasikan pestisida dengan cara di semprot. Penyemprotan tanaman kentang biasanya dilakukan pada pagi hingga siang hari dengan rentang waktu mulai dari 15 menit sekali penyemprotan hingga 4 jam penyemprotan, tergantung dari luas lahan pertanian dan tekhnik penyemprotanya. Penyemprotan pestisida dalam 1 kali periode tanam berkisar antara 15 - 20 kali, 15 25 kali, dan 20 - 30 kali. Perbedaan frekwensi penyemprotan dalam periode tanam tergantung dari musim, apabila musim hujan tiba maka frekwensi penyemprotan akan di tingkatkan.

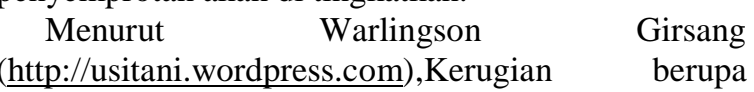
timbulnya dampak buruk penyemprotan pestisida, dapat dikelompokkan atas 3 bagian :

1. Berpengaruh negatif terhadap kesehatan manusia. Apabila penggunaan pestisida tanpa diimbangi dengan perlindungan dan perawatan kesehatan, orang yang sering berhubungan dengan pestisida, secara lambat laun akan mempengaruhi kesehatannya. Pestisida meracuni manusia tidak hanya pada saat pestisida itu digunakan, tetapi juga saat mempersiapkan, atau sesudah melakukan penyemprotan. Kecelakaan akibat pestisida pada manusia sering terjadi, terutama dialami oleh orang yang langsung melaksanakan penyemprotan. Mereka dapat mengalami pusingpusing ketika sedang menyemprot maupun sesudahnya, atau muntah-muntah, mulas, mata berair, kulit terasa gatal-gatal dan menjadi luka, kejang-kejang, pingsan, dan tidak sedikit kasus berakhir dengan kematian. Kejadian tersebut umumnya disebabkan kurangnya perhatian atas keselamatan kerja dan kurangnya kesadaran bahwa pestisida adalah racun. Pestisida sering ditempatkan sembarangan, dan saat menyemprot sering tidak menggunakan pelindung, misalnya tanpa kaos tangan dari plastik, tanpa baju lengan panjang, dan tidak mengenakan masker penutup mulut dan hidung. Juga cara penyemprotannya sering tidak memperhatikan arah angin, sehingga cairan semprot mengenai tubuhnya. Bahkan kadang-kadang wadah tempat pestisida digunakan sebagai tempat minum, atau dibuang di sembarang tempat.

Kecerobohan yang lain, penggunaan dosis aplikasi sering tidak sesuai anjuran. Secara tidak sengaja, pestisida dapat meracuni manusia atau hewan ternak melalui mulut, kulit, dan pernafasan. Sering tanpa disadari bahan kimia beracun tersebut masuk ke dalam tubuh seseorang tanpa menimbulkan rasa sakit yang mendadak dan mengakibatkan keracunan kronis. Seseorang yang menderita keracunan kronis, ketahuan setelah selang waktu yang lama, setelah berbulan atau bertahun. Keracunan kronis akibat pestisida saat ini paling ditakuti, karena efek racun dapat bersifat karsiogenic (pembentukan jaringan kanker pada tubuh), mutagenic (kerusakan genetik untuk generasi yang akan datang), dan teratogenic (kelahiran anak cacad dari ibu yang keracunan).

2. Berpengaruh buruk terhadap kualitas lingkungan.

Masalah yang banyak diprihatikan dalam pelaksanaan program pembangunan yang berwawasan lingkungan adalah masalah pencemaran yang diakibatkan penyemprotan pestisida di bidang pertanian, kehutanan, 
pemukiman, maupun di sektor kesehatan. Pencemaran pestisida terjadi karena adanya residu yang tertinggal di lingkungan fisik dan biotis disekitar kita. Sehingga akan menyebabkan kualitas lingkungan hidup manusia semakin menurun.

Pencemaran dapat terjadi karena pestisida menyebar melalui angin, melalui aliran air dan terbawa melalui tubuh organisme yang dikenainya. Residu pestisida sintesis sangat sulit terurai secara alami. Bahkan untuk beberapa jenis pestisida, residunya dapat bertahan hingga puluhan tahun. Beberapa hasil monitoring residu yang dilaksanakan, diketahui bahwa saat ini residu pestisida hampir ditemukan di setiap tempat lingkungan sekitar kita. Kondisi ini secara tidak langsung dapat menyebabkan pengaruh negatif terhadap organisme bukan sasaran. Oleh karena sifatnya yang beracun serta relatif persisten di lingkungan, maka residu yang ditinggalkan pada lingkungan menjadi masalah.

Residu pestisida telah diketemukan di dalam tanah, ada di air minum, air sungai, air sumur, maupun di udara. Racun pestisida kemungkinan terdapat di dalam makanan yang kita konsumsi sehari-hari, seperti sayuran dan buah-buahan. Penyemprotan pestisida dari udara jauh memperbesar resiko pencemaran, dengan adanya hembusan angin. Pencemaran pestisida di udara tidak terhindarkan pada setiap aplikasi pestisida, karena hamparan yang disemprot sangat luas. Sebagian besar pestisida yang disemprotkan akan terbawa oleh hembusan angin ke tempat lain yang bukan target aplikasi, dan mencemari tanah, air dan biota bukan sasaran.

3. Meningkatkan perkembangan populasi jasad tanaman penganggu

Tujuan penggunaan pestisida adalah untuk mengurangi populasi hama. Akan tetapi dalam kenyataannya, sebaliknya malahan sering meningkatkan populasi jasad pengganggu tanaman, sehingga tujuan penyelamatan kerusakan tidak tercapai. Hal ini sering terjadi, karena kurang pengetahuan dan perhitungan tentang dampak penggunaan pestisida.

Pestisida umumnya adalah bersifat racun kontak, perilaku dan penggunaan alat pelindung diri saat penyemprotan berpengaruh terhadap jumlah masuknya partikel pestisida ke dalam tubuh petani. Keselamatan dan Kesehatan Kerja (K3) petani kentang,di Desa Dieng, Kecamatan Kejajar, Kabupaten Wonosobo termasuk dalam kategori baik, dari 138 petani yang dijadikan subyek penelitian $101(73,18 \%)$ petani termasuk dalam kategori baik, sedangkan sisanya $37(26,82 \%)$ petani termasuk dalam kategori buruk.

Hal - hal yang mengakibatkan buruknya Keselamatan dan Kesehatan Kerja (K3) petani kentang antara lain : tidak menggunakan masker saat mengaplikasikan pestisida, tidak menggunakan penutup kepala saat mengaplikasikan pestisida, jumlah pestisida yang digunakan tidak sesuai dengan jumlah yang tercantum pada kemasan, mengenakan celana pendek saat mengaplikasikan pestisida, mencampur lebih dari 1 pestisida dala sekali penyemprotan, menyemprot pestisida pada waktu turun hujan atau pada waktu cuaca terik, membuang bungkus pestisida di sembarang tempat dan tidak mencuci peralatan semprot setelah penyemprotan.

Menurut Peraturan Menteri Tenaga Kerja dan Transmigrasi Republik Indonesia No 08 Tahun 2010, alat pelindung diri pestisida meliputi : alat pelindung kepala, alat pelindung mata dan muka, alat pelindung telinga, alat pelindung pernafasan beserta perlengkapanya, alat pelindung tangan, alat pelindung kaki dan pakaian pelindung.

Penggunaan pestisida yang kurang baik dapat menimbulkan keracunan baik yang bersifat akut maupun kronis. Keracunan akut dapat menimbulkan kematian secara mendadak. Keracunan akut diukur berdasarkan nilai dosis lethal (LD 50). Keracunan kronis adalah keracunan nyang disebabkan oleh pemaparan rendah dalam jangka panjang atau pemaparan dalam jangka singkat dengan akibat kronis. Keracunan kronis dapat ditemukan dalam bentuk kelainan syaraf dan perilaku (bersifat neutotoksik) atau mutagenitas. (Nusa Idaman Said, 1999)

Penyemprotan pestisida akan berada di udara dan lama kelamaan akan jatuh ke tanah. Untuk jenis pestisida yang tidak mudah menguap akan berada di dalam tanah terutama golongan Organoklorin karena sifatnya yang persisten. Walaupun pestisida dalam tanah dapat didegradasi oleh mikroorganisme. (Rosliana dalam Juli Soemirat, 2009, hal. 153).

Pestisida yang disemprotkan pada tanaman tentunya akan meninggalkan residu. Residu pestisida terdapat pada semua tubuh tanaman seperti batang, daun, buah dan juga akar. Khusus pada buah, residu ini terdapat pada permukaan maupun daging pada buah tersebut. Walaupun sudah dicuci atau dimasak residu pestisida ini masih terdapat pada bahan makanan. (Juli Soemirat, 2009, hal 155).

Hasil pemeriksaan Laboratorium Penelitian dan Pengujian Universitas Gadjah Mada, Yogyakarta terhadap sampel tanah untuk pengujian kandungan Organochlorin p;p-DDT $61,47 \mu \mathrm{g} / \mathrm{kg}$, sedangkan 8 parameter uji lainya masih dibawah batas kemampuan deteksi alat. Meskipun DDT telah dilarang penggunaanya di Indonesia sejak Tahun 1995 tetapi masih ditemukan residunya di tanah pertanian kentang Desa Dieng, hal ini disebabkan karena DDT merupakan pestisida yang dulu banyak digunakan, tetapi ternyata sangat persisten di tanah, bahkan setelah dilarang banyak petani yang masih menggunakan DDT karena dikenal sebagai pestisida yang dapat menangani seluruh hama tanaman dan harganya relative murah. Sehingga dimungkinkan adaya residu DDT pada tanah di lahan pertanian Desa 
Dieng merupakan residu dari pemakaian terdahulu atau masih adanya pemakaian DDT oleh petani kentang secara sembunyi - sembunyi hingga sekarang, hal ini perlu diklarifikasi dan diteliti lebih lanjut.

Pestisida golongan Organochlorin sedikit digunakan di Negara berkembang karena mereka memperhati secara kimia bahwa insektisida Organochlor adalah senyawa yang tidak reaktif, memiliki sifat yang sangat tahan lama atau persisten, baik dalam tubuh maupun dalam lingkungan memiliki kelarutan yang sangat tinggi dalam lemak dan memiliki kemampuan terdegradasi yang lambat (Ruchiawat dalam Juli Soemirat, 1996, hal. 144).

Sebuah penelitian risiko ekologi dilakukan untuk mengevaluasi kembali dan meninjau keseluruhan resiko residu pestisida untuk daerah perairan. Bila dibandingkan dengan Orhganophospat, Karbamat, dan pestisida lainya, penilaian analisis resiko menunjukkan bahwa pestisida Organochlorin persisten dan sangat beracun, dan terus menimbulkan kerusakan ekologis. Resiko yang terjadi adalah baik jangka panjang, jangka pendek akut dan sub akut, toksisitas kronis offside, terhadap organisme non target invertebrate air dan ikan salmon. Sifat fisik kimia residu pestisida baik dari senyawa individu ataupun beberapa senyawa dalam kombinasi, juga mempengaruhi sifat dampak biologis pada non target, organism air. (Michael T WAN dalam Journal of Environmental Science and Health Part B, 2013 ).

Organochlorin masih digunakan di negara sedang berkembang terutama pada daerah ekuator karena murah, efektif, dan persisten. Organochlorin dibagi menjadi beberapa bagian yaitu diklorodifenil etan (antara lain DDT, DDD, portan, metoksiclor, meticlor), siklodin (antara lain aldrin, dieldrin, heptachlor, chlordane, dan endosulfan), dan sikloheksan benzene terklorinasi (antara lain HCB, $\mathrm{HCH}$ ). Semua Organochlor adalah racun syaraf. Contoh dari Organochlor adalah DDT. (Juli Soemirat, 2009, hal. 144).

DDT merupakan insektisida yang ampuh untuk membunuh serangga hama yang menyerang sayur sayuran, palawija dan juga tanaman perkebunan. Disamping itu juga sangat ampuh untuk membunuh nyamuk penyebab penyakit malaria. Insektisida ini harhganya relative murah, maka tidak mengherankan kalau digunakan orang secara meluas. Namun pada tahun 1973 diketahui bahwa DDT ini ternyata sangat membahayakan bagi kehidupan maupun lingkungan, karena meninggalkan residu yang terlalu lama dan dapat terakumulasi dalam jaringan melalui rantai makanan. DDT ternyata sangat stabil baik di air, tanah dan dalam jaringan tanaman dan hewan. DDT tidak mudah terurai oleh mikroorganisme, enzim, panas atau sinal ultraviolet. (Subiyakto Sudarmo, 1995, hal.34).

Mekanisme terjadinya efek akibat terpapar pestisida sub golongan DDT yaitu umumnya terjadi pada perifer pada system syaraf sensor.
Menghasilkan negative potensial yang lama dengan menginhibisi enzim, yang diperlukan untuk transport ion, hasilnya adalah persisten depolarisasi. (Ruchirawat dalam Juli Soemirat, 2009, hal. 145).

Sejarah DDT pertama kali dikenalkan sebagai zat penolak serangga yang sangat efektif oleh Paul Muller di Switzerland . Pada tahu 1969 beberapa daerah di Arizona menggunakan DDT untuk keperluan pertanian. Kemudian pada tahun 1973 penggunaan DDT dilarang di Amerika karena sangat membahayakan bagi kehidupan dan lingkungan. (Subiyakto Sudarmo, 1995, hal. 14).

Walaupun di Negara -negara maju (Khususnya di Amerika Utara dan Eropa Barat) penggunaan DDT telah dilarang, di Negara - Negara berkembang terutama India, RRC, dan Negara - Negara Afrika serta Amerika Selatan, DDT masih digunakan. Banyak Negara yang telah melarang penggunaan DDT kecuali dalam keadaan darurat terutama apabila muncul wabah, seperti malaria, demam berdarah, dan sebagainya. Izin untuk menggunakan DDT dalam keadaan darurat oleh karena insektisidanya alternative lebih mahal, lebih toksik, dan tidak seefektif DDT. Departemen Pertanian RI telah melarang penggunaan DDTdi bidang pertanian, sedangkan larangan penggunaan DDT di bidang kesehatan dilakukan pada tahun 1995. Komisi Pestisida RI juga sudah tidak mengizinkan bagi penggunaan pestisida golongan hidrokarbon berchlor (chlorinated hydrocarbon) atau organochlorin. (Ishartadiati dalam Yudith Anindya, http://www.academia.edu.com ).

Hasil pengujian sampel kentang untuk kandungan Organophospat dari 6 parameter uji, semuanya di bawah batas deteksi alat dan jenis parameter yang di ujikan tidak tercantum pada Lampiran Keputusan Bersama Menteri Kesehatan dan Menteri Pertanian No 881/1996 dan No 771/1996, tentang Batas Maksimum Residu Pestisida pada Hasil Pertanian "Kentang", dimungkinkan parameter uji yang diperiksa untuk golongan Organophospat tidak diperbolehkan ada di kentang sehingga tidak tercantum dalam Lampiran Keputusan Bersama Menteri Kesehatan dan Menteri Pertanian tersebut. Disarankan kepada peneliti berikutnya untuk memeriksa jenis pestisida yang ada di Lampiran Keputusan Bersama Menteri Kesehatan dan Menteri Pertanian No 881/1996 dan No 771/1996, tentang Batas Maksimum Residu Pestisida pada Hasil Pertanian agar nantinya hasil uji dapat dibandingkan.

\section{IV.KESIMPULAN}

1. Jenis pestisida yang digunakan petani kentang di Desa Dieng, Kecamatan Kejajar, Kabupaten Wonosobo Tahun 2015, berdasarkan bahan aktifnya adalah Mankozeb, Azokistrobin, Difenokonazol, Karbosulfan, Klorotalonil, Simoksanil, Karbofuran, Dimetomorf, Endosulfan, Prefenofos, Karboril, Dimehipo, Klorpirifos, Propineb, Metiram Komplek , 
BPMC, Diazinon, Propargit, Tetradifon dan Karbendazim. Jenis pestisida berdasarkan fungsinya adalah Fungisida, Insektisida dan Akarisida. Kemudian jenis pestisida berdasarkan golonganya adalah Ditiocarbamat, Pirimidin, Azol, Karbamat, Organophospat, Urea, Organochlorin, Neristoksin, Azol, Fenoksi, Tetradifon dan Benzimidazol.

2. Jumlah pestisida yang digunakan petani kentang di Desa Dieng, Kecamatan Kejajar, Kabupaten Wonosobo Tahun 2015, dalam bentuk powder (tepung) untuk rentang terendah yaitu $1 \mathrm{~g}-3.250$ g adalah 99 pengguna $(74,43 \%)$ dari jumlah seluruh pengguna pestisida bentuk powder, sedangkan untuk rentang tertinggi $9.751 \mathrm{~g}-$ $13.000 \mathrm{~g}$ adalah 4 pengguna $(3,02 \%)$. Jumlah pestisida dalam bentuk liquid (cair) untuk rentang terendah $1 \mathrm{ml}-1.875 \mathrm{ml}$ adalah 102 pengguna $(90,26 \%)$ dari jumlah seluruh pengguna pestisida bentuk liquid, sedangkan untuk rentang tertinggi $5.626 \mathrm{ml}-7.500 \mathrm{ml}$ adalah 1 pengguna $(0,89 \%)$. Jumlah pestisida dalam bentuk granule (butiran) untuk rentang terendah $1 \mathrm{~g}-750 \mathrm{~g}$ adalah 34 pengguna $(77,27 \%)$ dari jumlah seluruh pengguna pestisida bentuk granule, sedangkan untuk rentang tertinggi $2.251 \mathrm{~g}-3.000 \mathrm{~g}$ adalah 2 pengguna $(4,55 \%)$ dari seluruh pengguna pestisida bentuk granule.

3. Petani kentang dengan jumlah 138 seluruhnya (100\%) mengaplikasikan pestisida dengan cara di semprot.

4. Keselamatan dan Kesehatan Kerja (K3) petani kentang,di Desa Dieng, Kecamatan Kejajar, Kabupaten Wonosobo termasuk dalam kategori baik, dari 138 petani yang dijadikan subyek penelitian 101 petani $(73,18 \%)$ termasuk dalam kategori baik, sedangkan sisanya 37 petani $(26,82 \%)$ termasuk dalam kategori buruk.

5. Hasil pemeriksaan Laboratorium Penelitian dan Pengujian Universitas Gadjah Mada, Yogyakarta terhadap sampel tanah untuk pengujian kandungan Organochlorin p;p-DDT 61,47 $\mu \mathrm{g} / \mathrm{kg}$, sedangkan 8 parameter uji lainya masih dibawah batas kemampuan deteksi alat. Sedangkan hasil pengujian sampel kentang untuk kandungan Organophospat dari 6 parameter uji, semuanya di bawah batas deteksi alat dan jenis parameter yang di ujikan tidak tercantum pada Lampiran Keputusan Bersama Menteri Kesehatan dan Menteri Pertanian No 881/1996 dan No 771/1996, tentang Batas Maksimum Residu Pestisida pada Hasil Pertanian "Kentang", sehingga hasil tidak dapat di bandingkan.

Saran untuk peneliti lain agar mengganti metode pemeriksaan pestisida dengan metode yang dapat mengukur residu pestisida secara kuantitatif dengan hasil pasti, tanpa ada kendala batas deteksi alat.

\section{DAFTAR PUSTAKA}

Andarwati, A.,U. (2011). Efisiensi Teknis Usaha Tani Kentang Dan Faktor Yang Mempengaruhi, Dalam Thesis , Sumatra Utara : Universitas Sumatra Utara.

Aziz Alimul Hidayat. (2007). Metode Penelitian Kebidanan dan Analisa Data, Jakarta: Salemba medika.

BPTP Sulawesi Selatan. (2011). Pengambilan Contoh Tanah untuk Analisis, from http://sulsel.litbang.pertanian.go.id , diakses tanggal 8 Februari 2015.

Des W Conel, dkk . (1995). Kimia dan Toksikologi. Jakarta : Indonesia University Press

Dinas Kesehatan Kabupaten Banjarnegara. (2013). Keracunan Pestisida, from http://vivanews.com , diakses tanggal 14 September 2014.

Eny Sofiatun, dkk. (2013). Study Sebaran Spasial Berbagai Golongan Pestisida Pada Lahan Pertanian Kentang di Desa Kepakisan, Kecamatan Batur, Kabupaten Banjarnegara Tahun 2013, dalam Karya Tulis Ilmiyah , Banjarnegara : Politekhnik Banjarnegara.

Hidayat Natawiguna. (1989). Pestisida dan Kegunaanya, Bandung : Armico

Juli Soemirat. (2009). Toksikologi Lingkungan, Yogyakarta : Gadjah Mada University Press.

Departemen Pendidikan dan Kebudayaan Republik Indonesia. (1995). Kamus Besar Bahasa Indonesia, Edisi Kedua, Jakarta : Balai Pustaka.

Kementrian Pertanian. (2012). Penggunaan Pestisida: from http://vivanews.com , diakses tanggal 14 September 2014.

Keputusan Bersama Menteri Kesehatan dan Menteri Pertanian No 881/Menkes/SKB/VIII/1996 dan 771/Kpts/TP.270/8/1996 tentang Batas Maksimum Residu Pestisida Pada Hasil Pertanian.

Masri Singarimbun dan Sofian Effendi. (1997). Metode Penelitian Survai, Jakarta : LP3ES,Fromhttp://books.google.co.id/masri/si ngarimbun/metode/penelitian. Diakses tanggal 15 Januari 2015.

Michael.T.WAN. (2013). Ecological Risk of Pesticide Residues in the British Columbia environment : 1973 - 2012 . Vol 48 (5), pp. 
$344-63$ : Journal Of Enfironmental Science and Health, Part B. From http://web.b.ebscohost.com/ehost/search/adva nced?sid=32650727-8083-475d-9ba8-

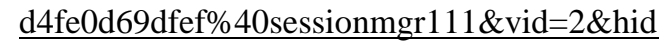
$=128$

Nusa Idaman Said. (1999). Kesehatan Masyarakat dan Tekhnologi Lingkungan, Deputi Bidang TIML, BPPT : Jakarta.

Novik Kurniati. (2012). Daftar Bahan Aktif dan Golonganya, From http://www.tanijogonegoro.com/2012/11/dafta r-bahan-aktif-pestisida.html, diakses 20 Januari 2015 .

Peraturan Menteri Tenaga Kerja dan Transmigrasi Republik Indonesia No 08 Tahun 2010 Tentang Alat Pelindung Diri..

Peraturan Pemerintah No 7 Tahun 1973 Tentang Pengawasan Atas Peredaran, Penyimpanan, dan Penggunaan Pestisida.

Peraturan Pemerintah No 66 Tahun 2014 Tentang Kesehatan Lingkungan..

Subiyakto Sudarmo. (1995). Pestisida, Yogyakarta : Kansius.

Suganda, dkk. 2002. Petunjuk Pengambilan Contoh Tanah. From http://balittanah.litbang.pertanian.go.id.pdf. Diakses pada tanggal 7 Februari 2015

Sugiyono. 2011. Statistik untuk Penelitian. Bandung : Alfabeta.

Suharsimi Arikunto. 2010. Prosedur Penelitian Suatu Pendekatan Praktek. Jakarta : Rineka Cipta.

Tri Cahyono. 2013. Pedoman Penulisan Proposal Penelitian dan Karya Tulis Ilmiah/ Skripsi
Edisi Revisi ke 3. Purwokerto : Poltekkes Kemenkes Semarang Jurusan Kesehatan Lingkungan Purwokerto.

Undang - Undang Republik Indonesia No. 19 Tahun 2013 tentang Perlindungan dan Pemberdayaan Petani.

Warlinson Ginsang. 2009. Dampak Negatif Penggunaan Pestisida: Staf Pengajar Fakultas Pertanian Universitas Simalungan, Pematang Siantar, Sumatera Utara. From htpps://usitani.wordpresss.com/2009/02/26/da mpak-negatif-penggunaan-pestisida/

WHO. 1986. Organophospharus Insectisides : A General Introduction Environmental Health Criteria 63. Geneva : WHO

Widianarko B., Vink K., Van Straalen N.M., 1994. Environmental Toxicologii in Shouth East Asia. Amsterdam : Proceeding, VU University Press.

Woro Wulandari. 2001. Studi tentang Penggunaan Pestisida Organopospate dan Carbonate pada Petani Kentang di Desa Depokharjo Kecamatan Parakan Kabupaten Temanggung Tahun 2001. Dalam Karya Tulis Ilmiah : Poltekkes Kemenkes Semarang.

Yudith Anindya. 2015. Kontroversi Penggunaan Pestisida DDT. From Http://www.academia.edu/5222235/Kontrover si_penggunaan pestisida_DDT diakses 27 Juni 2015

Yusnani, dkk. 2013. Identifikasi Residu Pestisida Golongan Organophospat pada Sayuran Kentang di Swalayan Lottemart dan Pasar Terong Kota Makassar Tahun 2013 dalam Riset. Makassar ; Hasanuddin University. 